\title{
The Use of Nigerian Pidgin in Media Adverts
}

\author{
Joseph Babasola Osoba ${ }^{1}$ \\ ${ }^{1}$ Department of English, University of Lagos, Akoka, Yaba, Lagos, Nigeria \\ Correspondence: Joseph Babasola Osoba, Department of English, University of Lagos, Akoka, Yaba, Lagos, \\ Nigeria. E-mail: jbosoba@yahoo.co.uk; jbosoba@gmail.com
}

$\begin{aligned} & \text { Received: November 27, } 2013 \\ & \text { Accepted: February 1, } 2014 \quad \text { Online Published: March 26, } 2014 \\ & \text { doi:10.5539/ijel.v4n2p26 }\end{aligned} \quad$ URL: http://dx.doi.org/10.5539/ijel.v4n2p26

\begin{abstract}
The use of Nigerian Pidgin seems to have gained a wider currency since Nigeria's independence in 1960. Among the educated and barely educated, the pidgin is used profusely in many spheres of life, especially in informal situations. In the mass media (television, radio, magazines and newspapers), schools, higher institutions of learning, government offices, etc., pidgin discourse abounds. In fact, despite the fact that it is not yet an official lingua franca in the country, it is a daily phenomenon in every day affair of an average Nigerian. The nature of Nigerian Pidgin, its easy mode of acquisition as well as the multilingual background of Nigerians may have been responsible for its present status and functions. In the light of the above, I am interested in how meaning is assigned to a piece of pidgin discourse, especially an advert in Nigerian Pidgin. Thus the goal of this paper is to establish how pidgin adverts communicate the intended meaning of their advertisers and how the audiences perceive them through an application of "Presupposition" and "Implicature" as conceptual or theoretical tools. These tools provide illuminating pragmatic insights and perspectives on Nigerian Pidgin media adverts.
\end{abstract}

Keywords: Nigerian Pidgin, Pidgin English, presupposition, implicature, media adverts

\section{Introduction}

Nigerian Pidgin may be described as the most vibrant of the over 500 languages (Akinnaso, 1989; Bamgbose et al., 1995) spoken in Nigeria today. In terms of currency, it may be described as the most widely spoken followed by the English, Hausa, Yoruba and Igbo respectively in Nigeria.

The reason for its wide currency may not be far-fetched. In many of Nigeria's cities such as Lagos, Kano, Sokoto, Ibadan, Port-Harcourt and Kaduna, Pidgin is the common language of the city people who come from diverse socio-cultural and linguistic backgrounds. The trend in Nigeria is that smaller towns are growing into big cities. Consider places like Akure, Ado-Ekiti, Benin, Minna, Aba and Owerri for instance. Their rapid growth status may be owing to the fact that they are state capitals, which makes them attract more people from rural communities as they search for greener pastures in the bigger towns and cities. Other places such as Ikare in Ondo State; Ilesha and Ile-Ife in Osun State, which are not state capitals, are equally growing in population for other reasons such as commerce, education, tourism and so on.

What is most noticeable and perhaps most significant is that in all those places, Nigerian Pidgin is also becoming the prominent common language. This growing popularity of Nigerian Pidgin (NP) is not restricted to social interaction. As far back as the early 60's, the late foremost Nigerian jazz and popular music icon, Fela Kuti, had adopted apart from Yoruba, his mother tongue, Nigerian Pidgin as the language of his music. From the 1960's until his death in 1997, he sang most of his music in Nigerian Pidgin (see Moore, 2010, p. 11). In fact, much (about 90\%) of his works from the 1970s until his death in 1997 was in Pidgin. Little wonder, in a Special Lecture at the Faculty of Arts, University of Lagos, on October 13, 2010, the Lecturer, Carlos Moore, advocated the use of Nigerian Pidgin as a national lingua franca. Agheyisi (1984), Elugbe and Omamor (1991), Osoba (2000) and others have earlier suggested the adoption of Nigerian Pidgin as a national common language. Some of the reasons adduced are as follows:

(i) It is the fastest growing common language in Nigeria today. From practical experience, it is noted to have the widest currency among Nigerians from diverse ethnic and linguistic backgrounds. In fact, this currency is reflected in the language of Nigerians from all walks of life, such as music, social interaction, religious activities/events, mass media broadcasting, and literary works even at the primary level of education in places like Asaba Warri, Sapele and Port-Harcourt. In Ajegunle Town, it is the most popular lingua franca for residents 
from diverse ethnic and linguistic backgrounds. Moreover, for the younger generation, it is fast becoming a creole for the vast majority of them who now speak it as a primary or first language. This trend was noted by Ifode (1983-1984) in the use of NP (which she erroneously termed Nigerian Pidgin English (NPE)) in Port-Harcourt.

(ii) In Nigeria, there are literary works that are either fully or partly written in Nigerian Pidgin.Major General Mamman Vatsa's poem, "Tori for Get Bow Leg"; Ken Saro Wiwa's Soza Boy; Aig Imoukhuede's "My Pidgin Stew and Sufferhead", Fadaka's Pidgin Translation of the Universal Human Rights are entirely in Pidgin. In the works of prominent Nigerian literary icons such as Wole Soyinka, Chinua Achebe, Festus Iyayi, Gabriel Okara, Nigerian Pidgin is evident.

(iii) As noted in my abstract, among the educated and barely educated, Nigerian Pidgin is profusely used in many spheres of life, especially in informal situations. Thus, in the mass media (television, radio, magazines and newspapers) hospitals, police stations, schools, higher institutions of learning, government offices, etc., Nigerian Pidgin is widely used.

In this paper, I attempt to employ presupposition and implicature based on Fairclough's Critical Discourse Analysis (CDA) for interpreting Nigerian Pidgin media adverts through an analysis selected electronics media texts. My goal is to establish how a piece of radio advert in Nigerian Pidgin communicates the intended meaning of the advertiser(s) through presupposition and implicature. This approach is significant because it provides an invaluable insight into implicit and explicit discourse features of Nigerian Pidgin adverts which attract advertisers and their agents to the use of the language for media adverts. A major implication of this is that the goal of reaching the greatest or highest number of potential consumers, clients or customers becomes easy to achieve or attain as a result of the nature, characteristics and use of Nigerian Pidgin.

\section{The Origin, Nature and Characteristics of Nigerian Pidgin}

The origin of Nigerian Pidgin may be difficult to state with precision. Evidence in literature points to the fact that, as far back as the eighteenth century, Nigerian Pidgin English, the forebear of Nigerian Pidgin, was already being used especially in the city states of the Niger Delta region (see Agheyisi, 1984, p. 211; Ogu, 1992, p. 85). As suggested by Agheyisi (1984), this early pidgin was used primarily, if not exclusively, in the restricted context of trade. But gradually, the social conditions as well as the introduction of schools by the missionaries and colonial governments led to its spread and development as noted by Flint (1960, p. 83):

... The absorption of large numbers of Ibo (Igbo) east of the Niger produced an extra-ordinary cosmopolitan effect, in which most cities became trilingual, speaking the native Ijo; Efik; Ibo (Igbo); and Pidgin English, the language of trade with Europeans. By the end of the eighteenth century, there were even rudimentary schools in Calabar for the teaching of Pidgin English, reading and writing with the object of producing clerks and book keepers.

Today, what Nigerians speak may be described as Nigerian Pidgin which developed from Pidgin English, a variety of English. Like any other human language, Nigerian Pidgin is not uniformly characteristic in all parts of Nigeria. In fact, varieties abound in all places, spheres and situations where it is found and used (see Marchese \& Shnukal, 1982; Agheyisi, 1984; Elugbe \& Omamor, 1991; Faraclas, 1996; Osoba, 2000).

Interestingly, as noted by Agbegisi (1984, p. 213), sociolinguistic profile of NPE (Nigerian Pidgin English) has not failed to produce some linguistic effects. Such a label as "Pidgin English" (or Pidgin or Broken English, alternative names for NPE) has come to be associated with a wide range of forms, united essentially by their negative classification as "non-standard English". Indeed, "Pidgin English" is used and understood, often loosely, to apply to all of those names or labels. Thus the erroneous name, "Pidgin English", is today still attached and given to "Nigerian Pidgin" which has now been observed to be a non-variety of English, but a linguistic system on its own (see Elugbe \& Omamor, 1991; Faraclas, 1996; Osoba, 2000). It is on this basis that my analysis is based on a sample of Nigerian Pidgin discourse found in the Nigerian media.

Ifode's (1983-1984, p. 201) attempts to put NPE in the general social context may also provide an insight as follows:

The main contexts of NPE use are markets, hotels, motor parks, government and private offices and schools at all levels. In markets and motor parks, it is the primary mode of communication. In the schools, NPE is prevented from becoming primary by the social stigma attached to it as a non-standard variety of the former colonial language. Some churches reproduce this stigma and hold on to Standard English, while others use NPE as the primary medium. The same can be said of offices, where social hierarchy is the primary determinant of pidgin use. 
In her attempt to determine whether or not NPE is creolising, Ifode (Ibid.) conducted an illuminating survey showing the number of children who used the language in Port-Harcourt (between the ages of 8 and 12 and living with their parents) as mother tongue, first language or primary language at home. The summary of her findings is tabulated below:

$\begin{array}{lllll}\text { FIRST LANGUAGE } & & \text { NPE } & \text { MT } & \text { UNKNOWN } \\ 4 & \text { NPE }(\mathrm{n}=20) & 6 & 10 & \\ 12 & \text { MT }(\mathrm{n}=38) & 10 & 16 & \\ \text { PRIMARY LANGUAGE } & \text { BOTH }(\mathrm{n}=12) & 4 & 3 & 5 \\ & \text { Total } & 20 & 29 & 21 \\ & \text { (Total } \mathrm{n}=70) & & & \end{array}$

From her summary above, out of a total of 70 children, 20 spoke NPE as their primary language; only 6 spoke it as their first language (FL) while 10 spoke their mother tongue first. To her, the most significant correlation which emerges here is a negative one: less than half of those who had either NPE or MT as a primary functional language were known to have had it as their first language; and correlation is worse for NPE (38\%) than with MT $(62 \%)$ by a very large margin if the unknowns are regarded as neutral. This is ironic in the sense that, in spite of its wide currency, NP is still perceived as a low/sub-standard variety of the English language especially among the educated speakers (see Bronahan, 1958; Obiechina, 1974; Adekunle, 1974, 1979). Ogu's (1992, p. 85) observation is illuminating in this regard:

The Nigerian Pidgin variety has also been identified by linguists. This is a variety that has become highly integrated into our Nigerian culture. It does not use English language structures, spelling, and phonology. When vocabularies are similar, they may not be identical. This variety is used all over the country so much so that it should be regarded as language of itself. However, in our situation in Nigeria, it is seen as a variety of English.

This is perhaps why media adverts in NP are set against the background of cordiality, intimacy, humuor, or other informal situations.

\section{NP Media Adverts as Communicative Exchanges}

From a layman's perspective, media adverts may be interpreted as any piece of linguistic communication. It may be described as a written or spoken form of language used in interaction by interlocutors. In every communication, the interlocutors tend to be concerned with the way information is organized. Thus any form of communication, such as dialogues, poetry, drama, prose, memos, letters, commentaries etc. in any linguistic form or language can also be described as a piece of discourse.

In his work, Language and Power, Fairclough (2001, pp. 16, 18-19) provides a fascinating conception of language as discourse, language as a form of social practice. In an attempt to make clear what discourse is, he differentiates discourse from text. To him, "a text is a product rather than a process-a product of the process of text production." In his work, the "term, discourse, is used to refer to the whole process of social interaction of which a text is just a part". This process is said to include both process of production and process of interpretation, for which the text is a resource.

Thus discourse is seen as involving two types of social conditions: (1) social condition of production and (2) social conditions of interpretation; which relate to three different "levels" of social organization, the level of the social situation, or the immediate social environment in which the discourse occurs; the level of the social institution which constitutes a wider matrix for the discourse; and the level of the society as a whole. In sum, discourse can be described as the relationship between texts, interactions and contexts. The following diagram by Fairclough (2001, p. 21) illustrates this: 


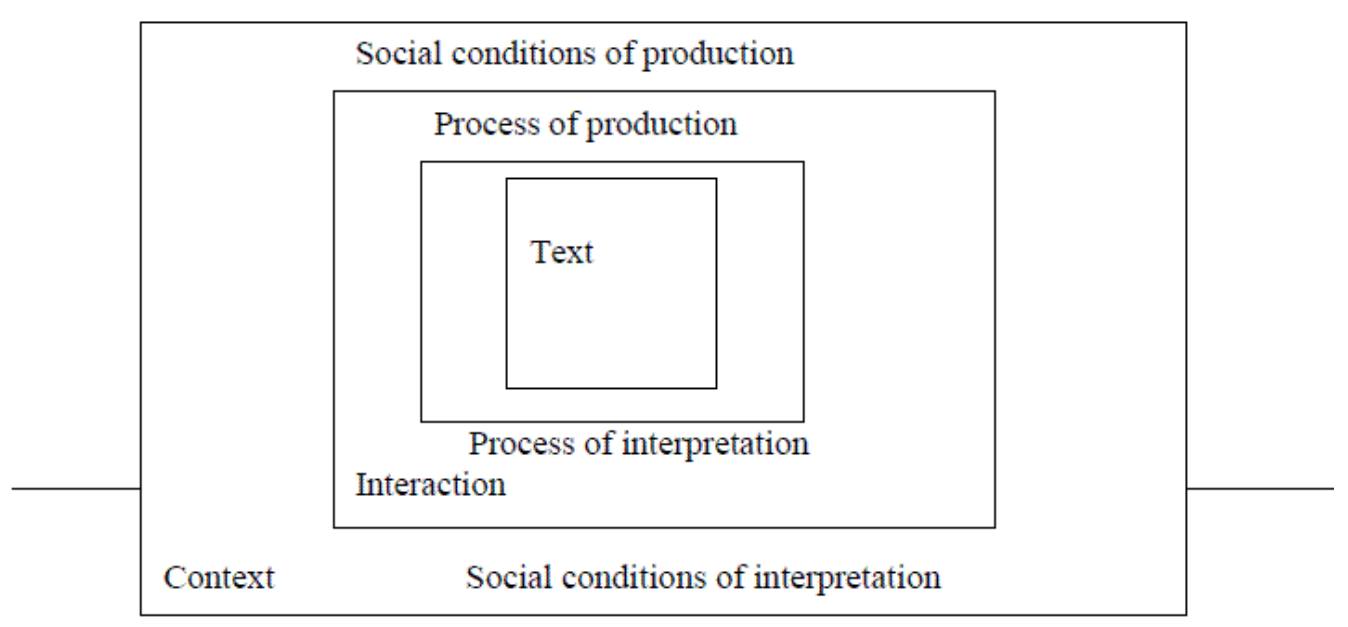

Figure 1. The relationship between texts, interactions and contexts

Following Fairclough's (2001) illuminating argument, I assume that media adverts in NP constitute a piece of discourse.

\section{Media Adverts in Nigerian Pidgin}

Nigerian Pidgin is used extensively in the nation radio networks for advertisement. The text of the adverts in Nigerian pidgin when considered in its relationship with its contexts as well as its advertisers and audience becomes a piece of discourse in the light of Fairclough's argument and propositions. As noted earlier, every use of language involves context, text and interlocutors. This is valid for every human language as it is for Nigerian Pidgin. Thus any use of NP for the purpose of interaction may be regarded as discourse. The notion of Nigeria pidgin may be valid therefore for samples of texts of media programmes and adverts.

Historically, Nigerian Pidgin (NP) was introduced into radio broadcasting in Nigeria by Mr. Frank Imoukhuede, a Director with Arts Department of the National Theatre in the 1980's. It started with request programmes in NP aired on Radio Nigeria 2. Radio Nigeria 3, which was established later, became a full-fledged Pidgin station. From its establishment till today, all its programmes are broadcast in NP. The name Radio Nigeria 3 was later changed to Wazobia FM in 1997 by the Federal Government of Nigeria. The reason for adopting NP is simply to be able to reach its largest audience at the grassroots level. Elugbe and Omamor (ibid, p. VI) observe

But NP is used unofficially in education, informally in religion and now, officially, in news broadcasting in Anambra, Bendel and Rivers States. This is happening both on the television and radio. Radio Enugu (now Anambra) is the latest addition to Broadcasting Stations which now provide news and other serious Programmes in NP.

This may suggest that presupposition is embedded in NP media adverts.

\section{Presupposition in NP Media Adverts}

In any linguistic enterprise, effective communication depends to a large extent on the shared knowledge or values that exist or prevail contextually among interlocutors. It is this shared knowledge or values that enhance the interlocutors correct interpretation of each other's utterances and messages. It is on this assumption that the pragmatic notion of presupposition rests. Yule (1996, p. 134) regards the assumption that the hearer and the speaker have about what they assume to be true as presupposition. To him,

When a speaker uses referring expressions like this, he or Shakespeare, in normal circumstances, she is working with an assumption that the hearer knows which referent is intended... What a speaker assumes is true or is known by the hearer can be described as a presupposition.

As noted earlier, linguistic messages are designed based on the assumptions about what hearers already know. These assumptions are based on the shared knowledge or values that exist among interlocutors but may sometimes be mistaken. Yule (1996, p. 132), Palmer (1996, p. 166), Mey (2001, p. 28) and Levinson (2003, p. 167-176) provide illustrative accounts of the notion of presupposition. Levinson (ibid, p. 173) illuminates a set of 
important distinctions and alternative approaches adopted by linguists as follows:

1) the distinction between logical implication or entailment and presupposition (in the work of Frege and Strawson )

2) the contrast between assertion and presupposition (again in the work of Frege and Strawson)

3) The issue of whether it was proper to think of presupposition as a relation between sentences (as Frege sometimes did) between statements (as Strawson held) or between speakers on the one hand and assumptions on the other (as Frege did, on other occasions).

4) the issue of whether the apparent ambiguity of negation between a presupposition- denying sense and a presupposition-preserving sense is to be thought of as a scope distinction (a structural ambiguity) or lexical ambiguity.

5) the possibility that apparently background assumptions, presuppositions, could in fact be viewed as assertions of entailments, on a par with the rest of a sentence's meaning(Russell's approach).

In addition, he lists a certain range of presuppositional phenomena that had been adduced in the philosophical literature which includes the presuppositions of

a. singular terms, e.g., definite descriptions, proper names

b. quantified noun phrases, e.g., "All of John's children" can be claimed to presuppose "John has children" (Strawson, 1952).

c. temporal clauses (as in Frege's example quoted above).

d. changes of state verb: e.g., "Betrand has stopped beating his wife" can be claimed to presuppose "Betrand had been beating his wife" (Sellar, 1954).

From his explication of the various approaches to and distinctions (Frege and Strawson, Strawson (1952), Russell, Sellar (1954) and so on) of presupposition, Levinson (2003) identifies two distinct kinds of presupposition in natural languages: (1) semantic presuppositions expounded by Strawson (1952) and (2) pragmatic presupposition as expounded by Keenan (1971). In the summary of his explication of semantic presupposition, Levinson (ibid, p. 204) clearly notes and asserts:

Semantic theories of presupposition are not viable for the simple reason that semantics is concerned with specification of invariant stable meanings that can be associated with expressions.

For this reason, and others catalogued by Stalnaker (1974); Kempson (1975), Wilson (1975) and Boer and Lycan (1978), semantic theories of presupposition have been abandoned and replaced or substituted with pragmatic presupposition whose basic concepts are appropriateness (or felicity) and mutual knowledge or common ground or joint assumption. This is indicated in his definition:

An utterance A pragmatically presupposes a proposition B if A is appropriate only if B is mutually known by participants.

Thus by uttering a sentence whose presuppositions are, and are known to be false, we are merely producing an inappropriate utterance, rather than (on the semantic view) to have asserted a sentence that was neither true nor false. Thus an NP advert may be accepted as been appropriate or not.

The approach I have adopted in this paper is that of Pragmatic Presupposition for the reason that it is more relevant and provides a sound basis for the explication and analysis of NP discourse corpus.

\section{Implicature in NP Media Adverts}

Implicature may be described as a principle or communication strategy which implies what the speaker does not actually say and what the hearer does not know (see Palmer, 1996, p. 173). This may be seen as one of the most complex nature of communication in the sense that both "speaker and hearer", or interlocutors must be very cooperative in their social interaction for efficient communication to take place. This principle, with four maxims, was first propounded or expounded by Grice (1975) (see Yule, 2006, p. 145). According to Grice, talk exchanges are characteristically "cooperative efforts" in which each participant recognizes a common purpose or set of purposes, or at least a mutually accepted direction (see Jianmin, 1999, p. 8). The four maxims or criteria supporting the principle are as follows:

Quantity: Make your contribution as informative as is required, but not more or less, than is required.

Quality: Do not say that which you believe to be false or for which you lack evidence. 
Relation: Be relevant

Manner: Be clear, brief and orderly.

Thus, the notion of implicature may be interpreted as suggesting additional or extra information or information beyond the literal sense. This is applicable to NP discourses in which interlocutors may have to interpret verbal exchanges, texts, and discourses beyond their ordinary or literal sense.

Having examined the relevance and usefulness of both notions/ theories of Presupposition and Implicature as they relate to NP discourses, I now apply them as analytical tools to demonstrate their strengths, relevance and adequacy in the interpretation of the samples of the NP Radio discourse.

\section{Methodology/Presentation of Corpus}

The data for analysis was collected through listening to pidgin broadcasts and adverts on Wazobia 95.1 FM; Rhythm 93.1; and Eko FM Radio. These radio stations are based in Lagos and employ NP as their language of newscasts, adverts and other programmes to reach their widest audience at the grassroots level. Some of data were tape-recorded in order to ensure playback which is useful when transcribing pidgin discourse. The data collection spread between a period of 17 years (from 1993-2010). Only samples of our data are actually extracted for the purpose of our analysis since they tend to suffice for the explication of the features of Presupposition and Implicature which is our goal. Each text (find details and Standard English translation of each text in the Appendix to this work) of our corpus is organised into clausal and phrasal structures. These are then organised into their categorial units. However, since we are dealing with discourse, only the clausal and phrasal structures are considered for analysis. The texts are presented as follows:

\section{Text 1}

Clause (1): Go dea

Clause (2): dem dey weit to elp yu o!

Clause (3): Go nao , an

Clause (4): rejista o !

Clause (5): Na onli wen yu regista

Clause (6): yu get rait to vot

Clause (7): Yo vot na im bi yo pawa o!

Clause (8): Di senta dem dey opin efreidey-bai-dey, from et o'klok fo di moni go rish sis o'klok fo ifni, from Monde etin May go rish Monde twenti-faif, 1992

Clause (9): Na di National Electoral Komishon

Clause (10): se mek wi kari dis tori rish yo domot ooo!

\section{Text 2}

Speaker A:

Clause(1): Wai yu waka pas manu laik dat?

Speaker B:

Clause(2): Kom o,

Clause(3): na tru se yu go Pikolo haus?

Speaker A:

Clause(4): Yes,a go si am.

Speaker A:

Clause(5): An yu toch am wit yo and?

Speaker B:

Clause(6): Ah ah, wai a no go toch am ,eh?

Speaker A:

Clause(7): Abi yu de creis?

Clause(8): Yu no kno se Pikolo don kari AIDS? 


\section{Text 3}

Speaker A:

Clause(1): If na moni fo skul, o ospita bil;

Clause(2): weda na moni fo haus,o serimoni;

Clause(3): if na moni fo chop, o tu bai haus;

Clause(4): kontakt obodo Oyibo, an

Clause(5): yo moni go land, expres!

Speaker B: (Many Voices)

Clause(6): UBA Moni Gram

\section{Text 4}

\section{Speaker A:}

Clause(1): Koret babes no de kari eni-hau bele!

Speaker B:

Clause(2): Yu don hia se a kari bele,

Clause(3): tok of se a go komot am ?

Clause(4): evin-sef, a nefa kash eni yanmayanma diziz

Clause(5): bikos a de uz kondom.

Speaker A:

Clause(6): Meki wi dey uz kondom plan tode an tomoro!

Speaker B:

Clause(7): Na tru tok mai sista.

Clause(8): If yu kari eni-hau bele,an

Clause(9): yu komot am, o

Clause(10): yu kash yanmayanma diziz,

Clause(11): yu fit skata yo shans to get pikin

Clause(12); wen yu don redi!

Clause(13): Bot wit kondom yu de kampe.

\section{Analysis: Texts 1, 2, 3 and 4}

For us to know whether Texts 1, 2, 3 and 4 are appropriate within the context of mutual knowledge, common ground or joint assumption, it is important to examine the background or setting of the production and interpretation of the texts.

From my earlier discussion of text and discourse, I assume that the texts to be considered are part of the Nigerian Pidgin discourse which Fairclough (2001) describes as “... the whole process of social interaction". This process is said to include both the process of production and the process of interpretation for which the text is a resource. I shall now examine the two types of social conditions in which the Nigerian Pidgin discourse is involved (1) social conditions of production and (2) social conditions of interpretation.

\subsection{Texts 1, 2, 3 and 4 and Social Conditions of Production}

These conditions operate at three levels as follows:

(1) the immediate social environment in which the discourse occurs;

(2) the social institution which constitutes a wider matrix for the discourse;

(3) the society as whole.

Texts 1-4 are produced for listeners of Radio Nigeria 3 (WAZOBIA FM) and Eko FM at the lowest social level in Nigeria, that is, people living in Ajegunle, Mushin, Oshodi, Obalende, Mile 2, Okokomaiko, Orile-Iganmu and other low-classed areas of Lagos State. Even though the radio station is situated in Ikoyi, a high-classed area of Lagos State, its programmes and adverts are directed at the low-classed Nigerians as its widest audience. Eko 
$F M$ is situated at Ikeja, the capital of Lagos State where majority of Lagosians work and live.

Since the purpose of Text 1 is to urge its audience to register so as to be able to participate in the up-coming elections it tends to be very appropriate. Text 2 is meant to create awareness about the Acquired Immune Deficiency Syndrome (AIDS), especially among poor Nigerians who live in low-classed areas and whose primary language is NP. This social condition makes the text quite appropriate.

The same social condition exists for Texts 3 and 4 which advise and recommend the use of UBA Money Gram for the transfer of funds from abroad because of its efficiency, and the use of condom to prevent AIDS respectively. Thus they are also considered appropriate. The reason for their appropriateness is simple. Most Nigerians who live in those places speak NP either as their common language or first, second, or even primary language. This provides a common ground, mutual knowledge, or joint assumption between the advertisers and the audience or the speakers and the listeners (interlocutors).

The use of the English language, or any other language in that context would have been inappropriate and would have the reduced the population of audience with mutual knowledge of the texts significantly. In fact, the purpose (which is to reach the widest audience at grassroots level) of placing the adverts in the media would have been defeated (from local evidence and statistics, less than $30 \%$ of Nigerians in urban centres such as Lagos speak good English). Statistics, as at 1990, shows that only 5\% of the entire Nigerian population speak the English language, which is the official language in Nigeria (see Atlaspedia Online).

Having examined the immediate environments of the texts, I now consider the level of the wider matrix of the institutions which produced them. Text 1 was produced by the National Electoral Commission, the body in charge of elections in Nigeria in 1993. In addition to its numerous adverts in English and the three major Nigerian languages (Hausa, Igbo and Yoruba), the NP text created the most significant awareness among Nigerians at the grassroots level.

Text 2 was produced by the media for the Federal Government as part of its awareness and enlightenment programmes on AIDS. As a responsible institution, Federal Government has a role to play in ensuring a good health for her citizenry, especially the poor masses. Thus Text 2 is significant as the best means of reaching Nigeria's teaming population of illiterate and semi-literate people. Moreover, mutual knowledge is usually demonstrated in a common language that is primary to people of low social class. This text makes the people closer to the responsibility of governance.

In the same vein, Text 3 produced by or for UBA, a banking institution is meant for the yearning masses that have relatives abroad who could assist them financially by transferring foreign currencies, especially the American Dollar or the British Pound Sterling to them. By employing this text, the institution appropriately communicates a message that meets the need of its prospective customers/clients at the grassroots level. The use of this text therefore demonstrates a common understanding or ground between the audience and the institution that produced it.

Text 4 produced by the manufacturers and/ or dealers/distributors of condom may also be considered appropriate because low-classed people are noted to be most sexually active and promiscuous. Lack of good education, ignorance and superstition tend to make people engage in unsafe sex. Some men and women believe that the use of condom could give irritation and some skin allergies because condom is artificial, so they avoid it. Some men believe that by putting incisions on their penises they could prevent themselves from contracting AIDS. Thus the of use Text 4 is appropriate because it communicates the important message that condom not only protect, to a large extent, people from contracting AIDS and other sexually transmitted diseases but also prevent unplanned pregnancies. By this text the institution (body, association) of manufacturers seems establish a common ground with the ignorant audience by educating them on why they should use condom. This is the institution's social responsibility to its immediate environment.

At the level of the society, the four texts can be assumed to be appropriate. The reason for this is that texts were generated to communicate certain messages which their audiences are expected to accept or be persuaded as being of significant benefits to them at this level, and in the context of these texts, any attempt to use the English text or that of any other language would have resulted in a fiasco. In fact, at this level, there is the pervasiveness of some common knowledge or assumption that Fairclough (ibid) calls "members' resources (MR)" between the producers and the receivers of the texts.

I shall now consider Texts 1, 2, 3 and 4 in relation to their social conditions of interpretation which also involve both their producers and their audiences. 


\subsection{Text 1, 2, 3 and 4 and Social Conditions of Interpretation}

The levels of immediate social environment, institution and society are also relevant under the Social Conditions of Interpretation. Texts 1, 2, 3 and 4 can be considered as appropriate when examined from the perspectives of the audience. In any kind of discourse, effective communication can only be said to have taken place when the feedback reflects that the intention of the speaker/producer has either been performed by or at least influenced, persuaded or convinced the listener/audience. What determines this is actually the mutual knowledge or common ground that exists between the interlocutors.

From all indications, the four texts demonstrate appropriateness and mutual knowledge or common ground that is the hallmark of pragmatic presupposition. Text 1 presupposes that the low-classed people are not usually well-informed about issues such as voter's registration and, when they are, they still require some persuasion. This makes clauses (1), (2) and (3) most appropriate here. The expressions in clauses (1) "Go dea", (2) "dem dey weit" and (3) "Go nao" are extremely persuasive. Clauses (4), (5), (6) and (7) explain the negative implication of not registering while clause (8) provides information about the duration or period of registration. These clauses therefore presuppose a common ground for moving Nigeria forward politically.

Text 2 presupposes that most Nigerians are ignorant of the nature of AIDS, as a deadly disease. This ignorance is evident in the text of the discourse of its interlocutors. From Text 2, it is clear that Speaker B did not understand that AIDS cannot be contracted by touching someone who had it. The text, in Clauses (6) and (8), simply shows the high level of ignorance of most people. Hence, the people need to be enlightened in a text that is most easily accessible to them. Thus this text can also be noted to be appropriate and to demonstrate a common ground to prevent the spread of AIDS among ordinary Nigerians.

Similarly, Texts 3 and 4 can be said to presuppose that people are always in need of money for various purposes including payment of children's fees, utility bills, mortgage, et cetera, and that most people dislike the use of condom, and, therefore, engage in unsafe sex respectively. The interpretation of the messages of Texts 3 and 4 becomes easy because the texts are couched in the language of masses, NP. The texts therefore are appropriate since they serve a common ground of interaction between the texts producers and their various audiences.

From analysis of Texts 1, 2, 3, and 4, it becomes clear that Pragmatic Presupposition is useful for the analyses of NP discourse. I now apply Implicature on the same texts.

\subsection{Implicature in Nigerian Pidgin Media Adverts}

Texts 1, 2, 3 and 4 are now analysed in terms of their implicature. Implicature theoretically relates to the meaning that may be outside the mutual knowledge of interlocutors. This meaning is said to be beyond the structure of a text, beyond its literal sense. It more or less relates to the non-linguistic interpretation of a text. As noted earlier, implicature is a principle which implies what the speaker does not actually say and what the hearer does not know. Evidence from the four texts suggests that each of them implies much more than what is actually said in it by its producers. Each of the clauses or phrases that make up each text tends to imply more than what is said in it linguistically.

Consider Text 1, for instance. Its Clause (1) says: Go dea which mean "Please go there". Here, the speaker did not say precisely where he wants the listener/audience to go. Even Clauses 2 and 3 do not say it. Clauses (4) and (5) which mention rejista (register) did not mention what the listener should register for. The mention of ... rait to vot (franchise) in Clause (6); yo pawa (your political weapon) in Clause (7) and di senta (centre) in Clause (8) only imply "the centre for the registration of voters" after they must have been read together with those in Clauses (1), (2), (3), (4) and (5), even though it is not directly stated in the text.

The four maxims supporting the principle of implicature can be applied to the text as follows: In terms of Quantity, in Text 1, each of Clauses (1), (2), (3), (4), (5), (6), and (7) may be said to have violated this maxim because it is not as informative as it should have. And it is only when Clause (8) is taken with (9) and (10) that it becomes adequately informative. Thus, Clauses (8), (9) and (10) also violate this maxim.

In terms of the maxim of Quality, all the Clauses may be said to conform with this criterion because the information in each of them is true and correct. This is also applicable to the criterion of Relation since the clauses are all relevant with respect to the information they provide. In terms of Manner, Text 1 may be regarded as clear, brief and orderly. This reflects in all its clauses except Clause (8) where enough/adequate information has to be provided about the registration period. From the foregoing analyses, it is clear that implicature provides a strong tool for the analysis of NP media discourse as evident in Text 1.

The maxims can also be applied to Texts 2, 3 and 4. Text 2 seems illuminating in terms of the criterion of Quantity. With the exception of Clauses (2) and (4) which are Imperative and Affirmative (structurally) 
respectively, the six others are interrogative. Thus Clauses (1), (3), (5), (6), (7) and (8) tend to elicit information rather than provide it. Then one may want to ask how much information should or can such a text provide in order to be considered enough or adequate. The use of interrogative clauses regarded as a communicative strategy under the principle of implicature to elicit or furnish information as an implication of what is not said.

Thus through this strategy Text 2 may be said to have satisfied the criterion of Quantity. It may also be said to have satisfied the criteria of Quality, Manner and Relation because all its eight clauses tend to elicit facts or true information, and are brief and clear, structurally, as well as relevant. These four criteria can be observed to apply to Texts 3 and 4 in a similar way.

\section{Conclusion}

From the foregoing analyses, it is possible to draw some illuminating inferences. This study explicates and highlights how and why Pidgin adverts communicate the intended meaning of their advertisers and how the audiences perceive them through an application of "Presupposition" and "Implicature" as conceptual or theoretical tools. These tools provide illuminating insights and perspectives on Nigerian Pidgin media adverts. Thus it is insightful that NP media adverts can be studied using relevant linguistic/discourse paradigms; and that presupposition and implicature are useful analytical tools for the explication of pragmatic perspectives on NP media adverts.

\section{References}

Adekunle, M. (1974). The Standard Nigerian English. Journal of English Studies Association (JNESA), 6(1), 24-37.

Agheyisi, N. R. N. (1984). Linguistic Implications of the Changing Role of Nigerian Pidgin English. In English World-Wide (pp. 210-241). Amsterdamin John Benjamins B. V. http://dx.doi.org/10.1075/eww.5.2.04agh

Akinnaso, F. N. (1989). One Nation, Four Hundred Languages: Unity and Diversity in Nigeria's Language Policy. Language Problems and Planning, 13(2). http://dx.doi.org/10.1075/lplp.13.2.03aki

Bamgbose, A., Banjo, A., \& Thomas, A. (1995). New Englishes: A West Africa Perspective. Ibadan: Mosuro.

Boer, S. G., \& Lycan, W. G. (1978). A Performadox in Truth-Conditional Semantics. Pragmatic Microfiche, 3(3), A3-C12. (Revised Version printed in Linguistics and Philosophy (1986)).

Brosnahan, L. F. (1958). English in Southern Nigeria. English Studies, 39, 97-110. http://dx.doi.org/10.1080/00138385808597010

Elugbe, B. O., \& Omamor, A. P. (1991). Nigerian Pidgin: Problems and Prospects. Ibadan: Heinemann Educational Books Nigeria Plc.

Fairclough, N. (2001). Language and Power. London: Longman.

Faraclas, N. G. (1996). Nigerian Pidgin. London: Routledge. http://dx.doi.org/10.4324/9780203192801

Flint, J. E. (1960). Sir George Goldie and the Making of Nigeria. London: Oxford University Press.

Grice, H. P. (1975). Logic and Conversation. In P. Cole, \& J. L. Morgan (Eds.), Syntax and Semantics: Vol. 3. Speecl Acts (pp. 41-54). New York Academic Press.

Ifode. (1983-1984). Is Nigerian Pidgin English Creolising? JOLAN, 2.

Jianmin, D. (1999). Business Writing: Using Interactional Language. Teaching English Forum, 37(3).

Keenan, E. L. (1971). Two kinds of Presupposition. In Fillmore, \& Langendoen (Eds.), Studies in Linguistic Semantics. New York: Hott, Rinehart Winston PP.

Kempson, R. M. (1975). Presupposition and the Delimitation of Semantics. Cambridge: Cambridge University Press.

Latimer Clarke Corporation Pty Ltd. (1993-2009). Atlaspedia Online. Retrieved from http://www.latimerclarke.com

Levinson, S. (2003). Pragmatics. Cambridge: Cambridge University Press.

Mey, J. L. (2001). Pragmatics: An Introduction. Oxford: Blackwell Publishing. http://dx.doi.org/10.1016/S0378-2166(01)80016-3

Moore, C. (2010). Fela: This Bitch of a life. Lagos: Cassava Republic.

Obiechina, E. N. (1974). Varieties Differentiation in English Usage. JNESA, 6(10), 80ff. 
Ogu, J. N. (1992). A Historical Survey of English and the Nigerian Situation. Calabar: Kraft Books Limited.

Osoba. (2000). Tense and Aspect in Nigerian Pidgin (Unpublished doctoral dissertation). University of Lagos.

Palmer. (1996). Semantics. Cambridge: Cambridge University Press.

Sellar, W. (1954). Presupposing. Philosophical Review, 63, 197-215. http://dx.doi.org/10.2307/2182346

Stalnaker, R. C. (1974). Pragmatic Presuppositions. In Rogers, Wall, \& Murphy (Eds.), Proceedings of the Texas Conference on Performatives, Presupposition \& Implicature. Washington: Centre for Applied Linguistics.

Strawson, P. F. (1952). Introduction to Logic Theory. London: Methuen.

Wilson, D. (1975). Presupposition and Non-Truth Conditional Semantics. London: Academic Press.

Yule, G. (1996). The Study of Language. Cambridge: Cambridge University Press.

\section{Appendix A}

Text 1

National Electoral Commission's Advert on Voters Regisration (May 1992)

(Source: Radio Nigeria 3, WAZOBIA FM 93.5)

Go dea, dem de weit fo yu o! Go nao an rejista o! Na onli wen yu regista Yu get rait to vot. Yo vot na im bi yo pawa o. Di senta dem de opin efri-de-bai-de from et o'klok fo di moni go rish sis o'klok fo ifnin from Monde etin May, go rish Monde twenti-faif 1992. Na di National Eletora Komishon se mek wi kari dis tori rish yo domot ooo.

An English Translation:

Please go there, they are waiting for you! Go and register now! It is when you register that you have the right to vote. Your vote is your power! The Centres open every day, from 8 o'clock in the morning to 6 O'clock in the evening, from Monday 18 to Monday twenty-five May, 1992.

\section{Text 2}

Media Advert on AIDS (September 2010)

(Source: Eko FM)

Speaker A: Wai yu waka pas man laik dat, nau?

Speaker B: Kom o, na tru se yo go Pikolo haus?

Speaker A: Yes, a go si am.

Speaker B: An yu tosh am wit yo and?

Speaker A: A a, wai a no go tosh am, eh?

Speaker B: Abi yu de creis? Yu no kno se Pikolo don kari AIDS?

An English Translation:

Speaker A: Why did you just walk away without saying, Hi?

Speaker B: Listen, is it true you went to Pikolo's house?

Speaker A: Yes, I did visit him.

Speaker B: And did you shake his hands?

Speaker A: Ah ah, why shouldn't I shake his hands, eh?

Speaker B: You must be crazy! Aren't you aware he has contracted AIDS? 


\section{Text 3}

United Bank for Africa (UBA)'s Advert on Money Transfer(Money Gram)

(Source: Eko FM, September 2010)

\section{Speaker A:}

If na moni fo skul, o ospita bil;weda na moni fo haus,o serimoni;

if na moni fo chop, o tu bai haus; kontakt obodo Oyibo, an yo moni go land, expres!

Speaker B:

Many Voices) UBA Moni Gram!

An English Translation:

\section{Speaker A:}

If it's school fees or hospital bills; if it's to build a house, or social events; if it's money for upkeep or mortgage, ask your relatives to transfer funds to you from abroad and you'll receive your money promptly!

Speaker B:

(Many Voices) UBA Money Gram!

\section{Text 4}

An Advert on the Use of Condom

(Source: Eko FM, 2010)

\section{Speaker A:}

Koret babes no de kari eni-hau bele!

\section{Speaker B:}

Yu don hia se a kari bele, tok of se a go komot am ? evin-sef, a nefa kash eni yanmayanma diziz bikos a de uz kondom.

\section{Speaker A:}

Mek wi dey uz kondom plan tode an tomoro!

\section{Speaker B:}

$\mathrm{Na}$ tru tok mai sista. If yu kari eni-hau bele,an yu komot am, o yu kash yanmayanma diziz, yu fit skata yo shans to get pikin wen yu don redi! Bot wit kondom ,yu de kampe.

An English Translation:

\section{Speaker A:}

Real ladies don't have unplanned pregnancies!

Speaker B:

Were you told I was ever pregnant or wanted to have an abortion? In fact, I've never contracted any sexually transmitted disease, just because I use condom.

\section{Speaker A:}

We should use condom to plan the present and the future!

\section{Speaker B:}

That's right, my sister. If you have an unplanned pregnancy or you abort it or you contract sexually transmitted diseases, you may forever miss the opportunity to be pregnant, especially when you need to! But with condom, you're secure!

\section{Copyrights}

Copyright for this article is retained by the author(s), with first publication rights granted to the journal.

This is an open-access article distributed under the terms and conditions of the Creative Commons Attribution license (http://creativecommons.org/licenses/by/3.0/). 